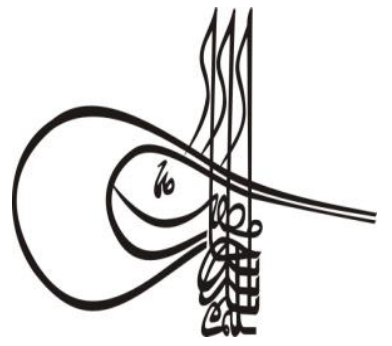

Received/Geliş: 06.07.2019

\section{Turkigh Studies}

Volume 14 Issue 6, 2019, p. 3127-3144

DOI: 10.29228/TurkishStudies.23498

ISSN: 1308-2140

Skopje/MACEDONIA-Ankara/TURKEY

Research Article / Araștırma Makalesi

Article Info/Makale Bilgisi

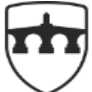

INTERNATIONAL BALKAN UNIVERSITY

EXCELLENCE FOR THE FUTUR IBU.EDU.MK

$\checkmark$ Accepted/Kabul: 15.10 .2019

an Report Dates/Rapor Tarihleri: Referee 1 (22.07.2019)-Referee 2 (23.07.2019)

This article was checked by iThenticate.

\title{
SANAT ESERİ BAĞLAMINDA ENTELEKTÜEL HEDONİZM
}

\author{
Nurhan ÇAMÖZ AÇIKBAŞ* - Ísa ELIRI $\dot{I}^{* *}$
}

\begin{abstract}
öz
Modern çağın manipüle edilmiş toplumları her şey yolundaymış gibi çağa ayak uydururken; gerçek sanat eseri ile iletişime geçen birey, doğası gereği aradığı en yüksek hazzı bulma çabasında olacaktır.

İnsan zihni sahip olduğu akıl ile yaşadığı evreni anlaşılır kılmaya çalışmaktadır. Bu anlayış onu nesnel bilgiye taşırken, yaşamdan da haz almasını sağlayacaktır. Adorno, sanatın sahip olduğu gücünü, temsil edilemeyeni, temsil etmekten aldığını ifade eder. Ayrıca estetiğe bağlı olarak bireyin sanat yolu ile özgürleşmesini sağlayanın da bu düşünce olduğunu beyan eder. Bu görüşler sanat eserinin sağladığı yüksek düzeydeki hazzı destekler mahiyettedir. Meydana getirdiği eserde izleyicilerin ortak paydada buluşması ise öznelerin aynı estetik beğeni ve estetik bilince sahip olmasındandır. Başka bir deyişle; bir yapıtın sanat eseri olması, o eserden alınacak estetik beğeni ve haz, bireyin duyarlılığ1 ile entelektüel bilgisinin uzandığı yere kadar olacaktır.

$\mathrm{Bu}$ araștırmamızda sanat eseri bağlamında entelektüel Hedonizm ile ilişkili olarak, sanatçı, sanat tüketicisinin sahip oldukları estetik bilinç ve entelektüel bilgiye dayalı olarak alınan entelektüel haz duyumu irdelenmiştir.

Sonuç olarak; sanatçının aşk ile var ettiği eseri ile kurduğu bağ ve oradan dışa yansıyanın izleyiciye ayna olması, belki de İnsana sunulan mucizelere tanık olma isteğinden kaynaklanmaktadır. Sanat eseri, kendi içinde gizlediği gücü karşısındaki insan aklının uzanabileceği en geniş alanlara kadar yayarak, insanlığın varoluş alanlarını genişletirken belki de kendi özünde yer alanı keşfetmesini sağlamaktır.
\end{abstract}

Anahtar Kelimeler: Sanat, Hedonizm, Sanat Eseri, Sanat Tüketicisi, Entelektüel Hedonizm.

Öğretmen-MEB, E-posta: siirimgelidya@gmail.com

Prof. Dr., Kırıkkale Üniversitesi Güzel Sanatlar Fakültesi, E-posta: isaeliri@hotmail.com 


\title{
INTELLECTUAL HEDONISM IN THE CONTEXT OF ART
}

\begin{abstract}
While the manipulated societies of the modern age keep up with the age as if everything is OK; The individual who communicates with the real work of art will, by nature, strive to find the highest pleasure he sought.

The human mind is trying to make the universe he lives in understandable with his mind. This understanding will carry him to objective knowledge and will also make him enjoy life. Adorno expresses that the power of art is derived from representing the unrepresentable. It also declares that it is this idea that allows the individual to be liberated through art, depending on aesthetics. These views support the high level of pleasure provided by the artwork. The meeting of the audience in the common denominator is that subjects have the same aesthetic taste and aesthetic consciousness. In other words; The fact that a work is a work of art, the aesthetic taste and pleasure to be received from that work will be up to the place where the individual's sensitivity and intellectual knowledge reach.

In this study, in relation to the intellectual hedonism in the context of the art work, the artist, the aesthetic consciousness of the consumer of art and the intellectual pleasure received based on the intellectual knowledge is examined.

As a result; the bond that the artist has created with love and the mirror reflected to the audience from the outside, perhaps because of the desire to witness the miracles offered to man. The work of art is to expand the areas of existence of humanity by expanding the power hidden within itself to the widest areas where the human mind can reach, perhaps to discover its own essence.
\end{abstract}

\section{STRUCTURED ABSTRACT}

Art will make the things in the work visible to the people who are not aware of and make sense of it. The meaning will be achieved according to the level of intellectual knowledge and knowledge that one has. The artist is able to convey cultural values and sociological elements that are not seen and seen by a large part of the society with his own intuition, emotional intelligence and intellectual comprehension.

Hedonism is the basis of the doctrine of pleasure; The artist exists with the object attributed to beauty and beauty for the artwork and the art audience. Whether something is beautiful depends on the subject and whether or not it receives pleasure, depending on sensations, not on objective knowledge through morality. No matter how much our sense of pleasure is perceived by our senses, it is not actually a pleasure of acting. Therefore, it is neither an experience of the senses nor the kind of satisfaction we have when we see action. 
The most important feature that distinguishes man from other living things is that he uses his thinking ability in his act of creation. The meeting of the audience in the common denominator is that subjects have the same aesthetic taste and aesthetic consciousness. In other words; The fact that a work is a work of art, the aesthetic taste and pleasure to be received from that work will be up to the place where the individual's sensitivity and intellectual knowledge reach.

If an artist paints a picture of nature, a human face or fruits standing on the table while adhering to reality, then the perception of this picture is limited to the reflection and reflection of these animated objects. This inner perception is accompanied by a special sense of enjoyment that has the characteristic of knowledge. Aristotle calls it sev glad to recognize while looking.. At the same time, while enjoying the beauty of the painted objects, one can be delighted by the mastery of painting those things. If a painting carries a poetic thought in itself and the imaginary form of the work has an effect that can convey these thoughts to the individual who cares, then the person who cares must receive the same sensation and pleasure in the same poetic thought dimension as the artist. Instead of making a statement and commenting on the objects depicted in the work, it would be more accurate for the artist to make a declaration on which knowledge and aesthetic anxiety and how he evaluates the objective world.

Intellectual life; art, culture, faith, morality, politics, and many areas of the human view of the world, it has enabled him to interpret and question the semantic nature. New living conditions, developing technology, and the reflection of human understanding of hedonism in the teachings of many philosophers from antiquity to this side also differed in art and artwork. As a result of an artistic expression since ancient times, this work of art aims to reveal the richness of the human mind and soul with an aesthetic appreciation. After the 15 th century, when human being interrogated the universe, he realized that his experience, knowledge and beauty as perceptive of the work of art and beauty depends on the appeal of his senses.

Art is a reflection of the intellectual life of society. The quality of the work that the artist creates will come as a force that will affect the society. It is known that the intellectual pleasure that will be obtained from the work will emerge with the interest and admiration of the human being. No matter how much the artist's experience and intellectual accumulation is reflected in the work, it will be as much as perceived by the art audience. As Rûmi says, en Whatever you say, what you say will be as much as the other person understands.'

Every society that captures the technology and intellectual knowledge of its era stands out as a necessity to show great interest in art. In the rapidly developing world, everything is consumed rapidly. The work of art should be accepted by the purchaser and should give pleasure and happiness besides the qualities it will have. The pleasure of art will be directly proportional to the intellectual equipment it possesses, apart from the relationship it will establish with the artist.

The work of art is a reflection of the power of reason which manifests itself and provides it. The intellectual knowledge and experience of the artist and the art purchaser is the most important 
element accompanying it. With the mind and the consciousness that accompanies it; to think, to create, to be happy, to get pleasure. The fact that a human being is a thinking entity has made it necessary for him to always learn and create new things. The curiosity of the human perception towards the unknown met with knowledge accompanied by reason and consciousness. Having intellectual knowledge has led to the reconstruction of the perception of thought, creation, experience and art. This fiction has also made the pleasure and happiness that he has experienced in life different.

As a result; the bond that the artist has created with love and the mirror reflected to the audience from the outside, perhaps because of the desire to witness the miracles offered to man. The work of art is to expand the areas of existence of humanity by expanding the power hidden within itself to the widest areas where the human mind can reach, perhaps to discover its own essence.

The feeling of pleasure, which is the result of the doctrine of hedonism, has been one of the most basic sensations that man has been in since his existence. Pleasure is the most important emotion that satisfies its vital needs, directs people to discover new things and separates them from other living things. Forbidden pleasure, which is the basis of religious teachings, is presented as a reward in other life. The pleasure of art and artwork not only draws people towards the knowledge and thought contained in them, but also causes them to feel the power and power they possess.

Keywords: Art, Hedonism, Artwork, Art Consumer, Intellectual Hedonism.

Modern çağın manipüle edilmiş toplumları her şey yolundaymış gibi çağa ayak uydururken; gerçek sanat eseri ile iletişime geçen birey, doğası gereği aradığı en yüksek hazzı bulma çabasında olacaktır.

İnsan zihni sahip olduğu akıl ile yaşadığı evreni anlaşılır kılmaya çalışmaktadır. Bu anlayış onu nesnel bilgiye taşırken, yaşamdan da haz almasını sağlayacak yegane unsur olacaktır. Adorno, sanatın sahip olduğu gücün, temsil edilemeyeni, temsil etmekten aldığını ifade eder. Ayrıca estetiğe bağlı olarak bireyin sanat yolu ile özgürleşmesini sağlayanın da bu düşünce olduğunu beyan eder. $\mathrm{Bu}$ görüşler sanat eserinin sağladığı yüksek düzeydeki hazzı destekler mahiyettedir.

Sanat olgusunun içinde, büyük ölçüde insanın sahip olduğu zeka, akıl ve yaratıcılık yer almaktadır. "Tolstoy, insanın bir zaman yaşamış olduğu duygu ve düşünceyi kendinde imgesel olarak var ettikten sonra, aynı duyguları diğer insanların da hissedebilmesi için, hareket, ses, çizgi, renk ya da kelimelerle belirlenen biçimlerde ifade etme ihtiyacı, sanatı ortaya çıkarmıştır" (Büyükdüvenci, 2006:47-50) der. Bu, insanın kendini var etme çabasından kaynaklanmaktadır. Sanatçı, duyma, görme ve algılama yetisiyle, diğer insanlardan farklı ve üstün olandır. Sanatçının vücuda getirdiği eser ise, estetik bilinç ve beğeni ile nesnel olarak şekillenendir. Eserle iletişime geçen insanların, aldığ haz ve mutluluk duygusu, bu bağlamda eseri değerli kılacak duygu aktarımıdır.

Sanatın amacı, bireyin tininde ve duyumlarında var olan her şeyi şekillendirerek somutlaştırmaktır. "Hegel'in şu ünlü "nihil humani a me alienum puto" sözü, "insanî olan hiçbir şeyi kendime yabancı saymam" (Hegel, 2012: 45-46). Sözündeki ifade, sanatın özünde olanın insanda var olanla müteşekkir olduğunu düşündürmektedir. Sanatın gücünü, insandaki gizli kalan duyguları, eğilimleri ve tutkuları canlandırıp huzur ve mutluluğa kapı açmasında hissetmekteyiz. İnsanın sahip 
olduğu entelektüel birikim, zihnin derinliklerinde yer alan bu duyguları aktif hale getirerek, eserden alınan haz noktasında taşıyacak olandır.

Sanat çoğu zaman, akıl ve duyular arasında zıtlıklar noktasında uzlaştırıcı ve arabulucu görevini üstlenmektedir. Bu örgütlenmedeki amaç eserdeki güzelliği, duyguya, sezgiye, imgesel dünyadaki özneye sunmaktır. Eserin anlaşılabilmesi ve güzelliğinden haz alınabilmesi, sanatçının sahip olduğu özgürlüğündendir. İnsanın yaşadığı evrende düşüncenin karanlık içselliği, sanat eserinin biçimlerinde huzur ve canlılığı arayışımızda ortaya çıkmaktadır.

Klee, “...Sanat görüntüyü kopya etmez, onu görünür duruma getirir” der (Leoir, 2003: 111). Sanat, eserde yer alan ve insanın farkında olmadığı şeylerin görülür duruma getirilmesine, ondaki anlamı yakalamasına neden olacaktır. Anlamı yakalamak ise, insanın sahip olduğu entelektüel birikim ve bilgi düzeyine göre gerçekleşecektir. Friedrich Schlegel'den A.Bowie'nin (1993) ifade ettiğine göre; sanat eserini, "temsil edilemeyenin temsili" olarak ifade etmektedir (Aktaran: Dellaloğlu, 1993: 54). Aslında bu, aynı düşüncenin farklı kelimelerle dile getirilmesidir. Sanatçı, toplumun büyük bir kesimi tarafından fark edilmeyen ve görülmeyen kültürel değer ve sosyolojik unsurları, kendi sezgisi, duygusal zekası ve entelektüel kavrayışı ile aktarabilmektedir.

Sanat eseri, sanatçının ruhunun özgün bir şekilde kurduğu estetik bir form birliğidir. Schiller 'İnsan güzellikle ancak oyun oynamalıdır' derken; amaç, sanatçıyı estetik hazlara konu olabilecek, çocuksu bir heyecan ve merak içinde, kendine özgü, eserler yaratmasını sağlamaktır. Sanatçı, kendi öznel dünyasında duyumlayıp algıladıklarını, sahip olduğu entelektüel bilgi ve deneyim ile harmanlayarak, esere estetik bir değer katmaktadır. Bu varyasyon, sanatçının tinsel dünyasının gücü ile var olan eserin, evrensel olmasını da olanaklı kılmaktadır.

Sanat eseri genellikle, toplum yaşamında kültürlerin oluşmasına etki eden unsurlardan estetik duyumun yansıması, olarak karşımıza çıkmaktadır. Sanat eseri yalnız duyulara dayanan bir fenomen olarak değil, temsil ettiği kültür içinde tini tanımlayan unsurlarla da var olmalıdır. Böyle bir var olmanın olmadığı yerde, sanat eserinden söz edilmesi mümkün olmayacaktır. İnsanın yaşadığı sosyal çevrede sahip olduğu norm ve değerlere bağlı olarak, meydana getirdiği eserin özne tarafindan algılanması ve deneyimlenmesi hayatı algılayışımız ve yüklediğimiz anlam ile birlikte, sanatsal içeriğin tüm değerleri ile örtüşecektir.

Alman felsefeci Hans Georg GADAMER ise; "Sanat eserinin, bir konunun belirsiz algilanma biçimlerini belirli bir yapıya kavuşturarak kendimizi ve dünyayı nasıl anladığımızı dönüştürebilmektedir"der. Bu diyalektik çerçevede, eserden çıkardiğımız sonuç kendimizi ve buna bağlı olarak bir sanat eserini, irademizle yaptıklarımıza ve kimi zaman eşit güçte kimi zaman ise karşıt yönde, bir konuyu nasıl algılamamız gerektiği yönünde etki oluşturabilecektir. Eser ile onun konusu arasındaki estetik alış verişe katılmamız, eser ile bağ kurmamıza vesile olacaktır. Üzerinde düşünülmeyen eylemlerimizin dağınık hali ufkumuzun yerini uzaktan belirleyen ön yargl, ahlaki normlar kendimizi ve yaratımlarımızı algllamamızı engeller. Sanat eserinde de yer alan belirsiz, parçalanmış ve yarısı gözden kaçmış algıları betimleyen bir yapıya kavuşturabilir" (Murray, 2009: 154-155).

Genellikle eylemlerimizi iç güdüsel ve bilişsel olarak, olarak farkında olmadan gerçeğin dışında yaşarız. Sosyolojik ve yaşamsal olarak deneyimlediğimiz şeyler meydana gelen eser üzerinde anlamın ve gerçeğin farkına varmamızı sağlar. Bu perspektiften bakıldığında sanat yaşantımız sırasında etkinleşen şeyleri dönüştürerek gözümüzün önünde var olan ancak göremediğimiz şeylerin, farkına varmamızı sağlar.

Sanatın, insan ruhu, bilinci ve istemi üstündeki etkisi, her zaman için somut tarihsel sınıfsal bir doğrultu göstermektedir. Psikolog L. S. Vigotski, bunu çok yerinde dile getirmektedir: "Sanat, toplumun kullandı̆̆g bir silahtır; sanatın yardımıyla toplum, bizim en gizli kalmış, en kişsisel 
yanlarımızla toplumsal yaşam alanı arasında bir iliş̧ki kurmuş olmaktadır. Sanat, bizim geleceğe karşı tavrımızın, ileriye ilişskin amaçlarımızın örgütlenişidir" (Kagan, 2008:446).

Sanatçının içinde yaşadığı sosyal toplum, kendi bilincini oluşturan estetik beğeniler, kendi yaşamına ilişkin tasarımları ona verendir. Sanatçı çoğu zaman, farkında olmadan toplumsal düşüncelerin taşıyıcısı, toplumsal çıkarların temsilcisi olarak, toplumun insanı çıkardığı yere taşımaktadır. Bu açıdan sanat, toplumun eğitilmesinde bir araç olarak, yeti olarak da tanımlanabilir. Eğitilmiş bir toplumun beğenileri ve tercihleri buna göre değişecektir. Sanat insanın bilincine en üst noktada etki eden bir yeti olarak karşımıza çıkmaktadır. Sanat eserlerinin kabul görmesi her toplumun kültürel yapısı entelektüel birikimi ve değerlerine göre farklılık gösterecektir. Sanat yapıtlarının farklı çağlarda ve farklı toplumlarda kabul görmesi ise onun evrensel niteliklere sahip olması ile ilintili olacaktır.

İnsanı diğer canlılardan ayıran en önemli özelliği, düşünme yetisini, yaratma eyleminde kullanmasıdır. Meydana getirdiği eserde izleyicilerin ortak paydada buluşması ise öznelerin aynı estetik beğeni ve estetik bilince sahip olmasındandır. Başka bir deyişle; bir yapıtın sanat eseri olması, o eserden alınacak estetik beğeni ve haz, bireyin duyarlılığı ile entelektüel bilgisinin uzandığı yere kadar olacaktır.

Hedonizm ögretisinin temelinde yer alan haz; sanatçı, sanat eseri ve sanat izleyicisi için güzelin ve güzele atfedilen nesne ile var olmaktadır. Kant ilk kitabı Salt Aklın Eleştirisinin Transendental Estetik bölümünde, duyarlılık ve algılama yetimizin transendental koşullarını, üçüncü eleştirisi olan Yarg1 Gücünün Eleştirisinde ise estetik duyarlılığımızın ya da diğer bir deyişle güzellik algımızın, transendental koşullarını incelemektedir. Yani yarg1 gücünün eleştirisi tüm özneler için evrensel ve zorunlu olan estetik ölçütleri incelemektedir. Kant'ın Yargı Gücünün Eleştirisi'nde, güzellik algısına dayanan estetik deneyim; "epistemolojik ya da teorik bir deneyim değildir. Bilinçli akılsal bir düşünüss süreci ve kavramsal soyutlama yetisinden ve aynı zamanda ahlaki veya etik deneyimden farklıdır. Estetik deneyim, güzel olarak nitelenen fenomenin duyumsanması sonucunda oluşan duygusal haz ve hoşnutluğa yol açan bir deneyimdir. Dolayısıyla ahlaki ve toplumsal ilgi ve çıkarlardan farklı ve özerk bir deneyim olarak, nesnenin yalnızca algılanmasına dayanmaktadır"(Orman, t.y.: 158).

Aynı zamanda Kant, estetik yargının evrensel niteliklere bağlı olması gerektiğini ifade etmektedir. Bu bir anlamda, estetik yargıyı, evrenselliğin anahtarı konumuna getirmektedir. Estetik deneyimi sadece duyu veya sıradan zevklerin değil, aynı zamanda bilim ve ahlaktan da özerk bir şey olarak konumlandırmıştır. Ona göre estetik yargının temel ve evrensel olan paradokslarından kaçış yoktur. Dolayısıyla Estetik yarg1, hoş ama tarafsız, bireysel ama evrensel, kendiliğinden ama zorunludur. Ve aynı zamanda kavramsız ama entelektüel, ahlaki ögretisi olmayan ama bizim ahlaki doğamızı açığa çıkaran bir şeydir (Shiner, 2013: 203). Bu görüş̧e göre, bir şeyin güzel olup olmadığ1, ahlak yoluyla nesnel bilgiye değil, duyumlara bağlı olarak özneye ve onun haz alıp almamasına bağlanmaktadır.

Estetik yargı ve deneyim, estetik bir seviyeyi ve birikimi işaret etmektedir. Algılayan özne algıladığı nesneye, kendi doğal ilgileri ve beğenileri bağlamında fark etmekten çok, yalnızca algılamak için var kılar. Bazen bu saf algısal deneyim içinde, estetik bir yargının sonucunda, özne hazza ulaşabilmektedir. Örneğin estetik deneyim içindeki özne, tablodaki meyveyi yemeyi düşünmekten çok, onları algılamaktan hoşnutluk duyabilmektedir. Böylece Kant düşüncesinde, güzelin bir değer olarak ortaya çıktığını ve bunun nesnenin kendinde değil süje'nin kendisinde bulunan estetik deneyim ve bilince bağlı olduğunu savunur.

Sanatın, insan yaşamına dair bilgisi ve dokunuşları eski çağlardan beri varlığını korumaktadır. Bunun olmadığı düşüncesi ise, o sanatın kâinattaki mucizelerden, tinsel değerlerden sonra maddeciliğe kısmen isyanı olmuştur. Sanatın içinde bulunduğu, bir yaşam insanın epükürcü ruhunun, mutluluğu ve 
huzuru bulmasına yol açabileceği gibi, aynı zamanda sanat, bütün karmaşanın ve anlamsız görünen bu evrenin bağlarından kurtulmuş bir ruha, evrenin veremediği hazzı sunabilecektir (Edman, 1991: 4243). Birey, sanatın hayata dair lütuflarından, iyiliklerinden sahip olduğu duyular aracıllı̆ı ile onun iletişim gücünü hissederek, haz almayı istemektedir. Yapılan veya düzeltilmesi gereken bunca yanlışlıklar ve acılarla dolu bir dünyada; sanat, hiçbir çıkar gözetmeden anlara en yüksek değeri ve hazzı vermemizi sağlamaktadır.

Güçlü bir Kant geleneği, belirli bir estetik haz türünde 1srar etmektedir. Bu haz, sosyokültürel nedenlerle kısitlanmakta olan zihinsel yetilerimizin ahenkli oyunundan doğan saf entelektüel bir zevk olarak tanımlanmaktadır. Pragmatik gelenek ise estetik zevke daha eli açık yaklaşmaktadır; rengin formun, biçimin, sesin, hareketin farklı nitelikleri olduğu gibi, duyularımızdan da kaynaklanan farklı zevkleri bulunmaktadır. Estetik deneyim açısından baktığımızda, bir sanat eserinin nitelikleri, algılarımızın olağan duruşundan farklı bir yerde durmaktadır. Estetik zevkler bazen o kadar yoğun bir haz ve mutluluk verir ki daha üst düzey bir düşünceye yani metafiziğe geçişten söz edilebilir hale gelebilmektedir (Hutter-Throsby, 2013: 58). Estetik zevkler yoğun ancak düzene konmuş duyguların deneyimiyle birlikte, önemli olma ve iletişim ihtiyacımızı tatmin eden anlam ve ifade doyumunu da içermektedir. Bu tür hazlar, yalnızca sanatçıyı değil, aynı zamanda deneyimledikleri zevkleri derinlemesine yorumlamaya çalışan sanat eleştirmenlerini ve sanata ilgi duyan sosyal toplumu da hedonizmin etkisi altına alabilmektedir.

Haz duygusu ne kadar duyularımız tarafından algılansa da o gerçekte edimlemeğe dair bir haz olmamaktadır. Bu nedenle, ne duyuların yaşadığı bir tecrübe, nede eylemi gördügümüz zaman sahip olduğumuz türden bir memnuniyettir.

$\mathrm{Bu}$ haz, sorunun çözümünü bulduğumuz zaman yaşadığımız ve o şeyin kendisini görmekten dolayı zihnimizin aldığı hazdır. Aynı zamanda, zihnin kendisine sunulan şeyi anlayıp kavramasından hemen sonra ortaya çıkandır. Zihnin kendi türünün arayışın da olan şeye ilişkin algısının neticesidir. Güzellikle ilgili şeylerde, zihin kendi kendine bu hissi verendir (Keeble, 2016: 183). Bu düşünceye göre, zihnin melekelerinde yer etmiş güzel algısı, estetik deneyim ile anlam bulabilmektedir.

Güzel, fark edilip görüldüğünde, hoşa giden ve keyif alınan şey olarak ifade edilmektedir. Güzel kavramını tecrübe eden, insanın kendi zihnidir. Güzelliğin sahip olduğu etki ile aydınlanan birey, duyularının gücü ile nesneleri fark etmektedir. Keeble, iyi bir şeyin gerçek olduğunu ve o gerçeğin de iyi bir şey olduğunu söylemektedir (Keeble, 2016: 185). Oysa Kant ve Schiller, estetik yargının nasıl ortaya çıktığının koşullarını, bu koşulların neler olması gerektiği hususunda aynı düşünceyi savunmaktadırlar. Kant, bir şeyin iyi olduğunu ifade etmek için amacının faydacılıkla alakalı olup olmadığına dair, o kavram hakkında her şeyi bilmemiz gerektiğini savunmaktadır. Ona göre, güzel için aynı şeyi söyleyemeyiz; gelişi güzel çizilmiş çizgiler, bize bir şey ifade etmezken yine de hoşa gidebilmektedir. Bu da güzel kavramının, salt estetik bir değer olduğunu kanıtlar mahiyettedir.

“Kant'a göre beğeni, kavramların veya kuralların, duyumsal zevkin veya faydanın uygulanışı haline getiren, sanat kuramların hepsi bir 'çıkar' ya da arzunun söz konusu olduğunu kabul etmektedir. Aslında gerçek 'estetik beğeni' yalnızca bir nesne üzerine derin düşüncelere daldığımız zaman söz konusu olan saf ve tarafsız bir zevktir" (Shiner, 2013: 201).

Kant'ın estetik tanımında, nesnel niteliğin kavranışını, zihnimizde olup bitenlerin, duyu yetilerimize yansıttığı bir uyarılma olduğunu görmekteyiz. Buradan yola çıkarak, Kant'ın hazdaki amacının, faydacılıktan ve çıkardan uzak, tam aksine beğeniye vurgu yaptığı söylenebilir.

Dış nesneler dünyası ve zekânın tam bir egemenliği altında bulunan yaratma eğilimi, eseri meydana getirilmesinden sonra haz ve zevk vermesine dair bir etkinliktir. Sanat yapitı dediğimiz eserlerde, mutluluğun eşlik ettiği haz ile düzenin var olduğu bir sosyal çevrede, insanın bütün endişeleri üzerine kendini hissettirecek olan zekânın diğer bir adıdır (Edman, 1991: 35). 
“...Salt yargılamada haz veren güzeldir. Sanatın her zaman bir şey üretme gibi belirli bir amacı vardır. Ama bu şey yalnızca beraberinde ve özünde haz olması gereken duyum olsaydl, o zaman bu ürün, yargllama ediminde, ancak duyusal duygu aractlı̆glyla haz verirdi. Ĕger amaç belirli bir nesnenin üretimine yönelik olsayd, o zaman ona sanat yoluyla erişilseydi, nesne yalnizca kavramlar yoluyla haz verirdi" (Kant, 2016: 118). Kant doğadaki güzellik ile sanattaki güzellik arasında farklılıkların olduğunu ifade etse de, aradaki ortak bağları da ifade etmeye çalışmaktadır. Sanat eserinin doğa değil, sanat olduğunun bilincinde olması gerektiğini, düşünmektedir. Ona göre güzel sanat, doğa olarak göründüğü ölçüde sanattır. Doğa evrende bir düzen içinde varlığını sürdürmektedir. $\mathrm{Bu}$ değişmez doğa kuralının duyumsanışı, her insanda farklı bir yansımaya bürünebilmektedir. $\mathrm{Bu}$ farklı ve değişik yansımalar, insandaki farklılığı ve entelektüel kavrayışı ortaya çıkarmaktadır.

Çoğu kişi için sanat, sadece duygulara hitap eden uyarım ve hazlardan oluşurken, insan ruhunun içinde yaşadığı dünyayı kendisine göre aydınlattı̆̆ için ise sanatın, edinilen deneyimler ile hayata bakış açısını değiştirmesine olanak sağlayan bir araç olduğunu görmekteyiz. Bu bakış açısından Sanat, farklı farklı eserler aracılığıyla, adeta bireyin bütün hayat tecrübesinin birikimi ve yöneldiği amacı haline gelmektedir.

Bir sanatçı gerçekliğe bağlı kalarak, bir doğa, bir insan yüzü veya masanın üstünde duran meyveler resmi yapmışsa, o zaman bu resmin algısı, canlandırılmış olan bu nesnelerin yalın bilgisiyle, yansımasıyla sınırlı olmaktadır. Bu iç algıya, bilgi özelliği taşıyan özel bir hoşlanma duygusu da eşlik etmektedir. Aristoteles buna, "bakarken tanımaktan dolayı sevinme" demektedir. Aynı zamanda, resmedilmiş nesnelerin güzelliğine bakmaktan haz alınırken o şeylerin resmedilmesindeki ustalık karşısında bir sevinç duyulabilmektedir. Kagan'a göre, sanat algısının somut özelliklerine ilişkin bütün bu alımlama biçimleri, ressamın kendi eserinde ortaya koyduğu ve o nedenle yaratmış olduğu yaşam üstüne bir düşünceyi, bir sanatsal bildirimi, o resme bakan kişinin nasıl kavradığını anlamamıza yardım etmemektedir (Kagan, 2008: 418). Dolayısıyla bir resim, kendi içinde bir şiirsel düşünce taşıyorsa ve eserin imgesel biçimi, bu düşünceleri bakan bireye iletebilecek bir etkisi varsa o zaman bakan kişinin de sanatçı ile aynı şiirsel düşünce boyutunda aynı duyumu ve hazzı alması gerekmektedir. Eserde resmedilmiş olan nesneler üstüne bir bildirim ve yorumda bulunmak yerine, o sanatçının bu nesneleri hangi bilgi yetisi ve estetik kaygı ile nesnel dünyayı nasıl değerlendirdiği üstüne bir bildirimde bulunması daha doğru olacaktır.

Eco, sanat alımlayıcısının sahip olduğu entelektüel birikim ve haz veren "şeyin, tanımlanmasında, hatta belirlenmesinde temel olan şeyin zevk olmayıp, nesnel estetik potansiyel olduğu savunur. Augustinus da bu sorun üzerinde durmuş, nesnelerin zevk verdikleri için mi güzel olduklarını, yoksa güzel oldukları için mi zevk verdiklerini sormuş ve öğretileri gereği ikinci varsayımın daha etkin olduğuna karar kılmıştır. Ama iradeye öncelik veren bir öğretide, zevk nesnenin belirlediği bir şey olmayıp, pekâlâ nesneye bilinçli olarak atfedilmiş bir şey olabilir” (Eco, 2017: 147) kanısına varmıştır.

İnsanın, sanat eseri olarak nitelendirilen bir yapıtı kavraması, onun estetik bir öge olarak görmesiyle anlam bulmaktadır. Buradan estetik objeyi alımlayan süjenin, estetik bir bilince de sahip olduğunu var sayabiliriz. Çünkü estetik bilince sahip bireyin, sanat eserinden de aynı derecede anlaması ve entelektüel bir haz alması beklenmektedir. Oysa çoğu zaman, sanat eserlerinden, süje dediğimiz varlığın aynı derecede haz almadığına tanık oluruz. Bunun nedeni ise, estetik obje dediğimiz nesneyle ilgili süjenin, sahip olduğu estetik bilinç ve bilgi yetisinin farklı oluşudur. Sanat eserlerinden haz duyan böyle bir süje, estetik deneyime ve bilince sahip bir insan olarak nitelendirilmektedir. Sanat eserinin amac1, bu süje için, obje olmaktır. Onunla kurulmak istenen ilgi, böyle bir bilince sahip süjeyle olanaklı kılabilmektedir. Sanat eserinden duyulacak haz, onu güzel ya da çirkin olarak değerlendirme yetisi, entelektüel bilince sahip olmakla ilişkili olacaktır. Dolayısıyla sanatçı, estetik yargı yetisi sonucunda nasıl dehası ile yaratıyorsa, onun yarattığı bu yapıt ile estetik ilgi kuran ve bu eseri estetik olarak yargılayan insanda beğeniye sahip olmaktadır. Bu anlamda beğeni, 
estetik bir objeyi estetik olarak değerlendirme yetisi diye anlaşılmaktadır. Bir sanat eseri yaratan sanatçı deha yetisine sahipken, sanat yapıtından haz duyan ve onu değerlendirme yetisine sahip yüksek entelektüel bireyde, beğeni yetisine sahiptir. Dehanın ve beğenenin bu özellikleri, bir yetenek olarak görülmekle birlikte her ikisinin arasında içten bir ilgi bulunduğu kabul edilmektedir (Tunalı, 2003: 170).

Sanattan alınan haz, insanda uyandırdığı mutluluk ve arınmayla gerçekliğin baskısından uzaklaşıp onu mutsuz eden bütün olumsuzluktan kurtulmanın sağladığı bir rahatlık ve dinginliktir. Aristoteles'inde ifade ettiği gibi bir ölü hayvan imgesinin bize verdiği zevkin ancak, sanatçının üstün becerisiyle ve ürettiği eserin gerçekdışı özellikte olması, bunun da mutsuz ve huzursuz olan izleyiciyi bir şey yapma zorunluluğundan kurtarmasıyla açıklanabileceği ileri sürülür (Leoir, 2003: 47). Burada eserin ayrıntılardan uzaklaşıp, eserdeki nesnenin özünü koruması, sanat alımlayıcısının ise her şeyi bir yana bırakıp sadece eserden aldığı hazza yönelmesi düşünülebilir.

Kant'a göre; Herhangi bir nesneden haz alıp almamak o nesne ile (apriori)doğuştan zihnimizde var olduğunu düşündüğümüz bilgiye duyular aracılığı ile bağlantı kurmak imkânsızdır. Çünkü bu deneyi aslında tecrübeyle elde edilen (a posteriori) bilgi algıyla bilinebilir. Öznenin çaba sarf etmeden ulaştığı olgular (yani görgül nesneler)dan alabileceğimiz haz duygusu öznenin zihninde oluşturduğu (duyulur üstü) niteliklerin anlama ve düşünme (us)yetisiyle ulaşılabilecektir. Estetiğe dair yargılarda da durum böyledir. Burada haz alınan nesnede hiçbir çıkar söz konusu değilken, ahlaksal yargıda kılgısal olduğu görülmektedir. Öznenin sahip olduğu bilgi yetisi de salt biçimsel erekliliğin bilinci nesnenin durumu hazzın kendisidir. Çünkü bir bilginin sınırlandırılmadan öznenin bilme yetisi nedenselliğini kapsar. Dolayısıyla estetik yargıda da öznel erekselliğin biçimini kapsar. Haz burada kılgısal değildir. Çünkü ne hoşlanmanın temel alındığı bir haz, nede iyinin entelektüel zemininden doğmuş bir hazdır. Ama yine de amacın olmadığı ve bilme yetilerin nedenselliğini kapsamaktadır (Kant, 2016: 53).

Kant doğada bir çiçeğin güzelliğini özgür güzellik olduğunu söylerken gül de bir amacın tezahür ettiğinin farkında olmayız der. Bir mimari yapıtın güzel olduğunu ifade ettiğimizde bir amaç kavramına sahip oluruz. Kant mimari yapıtın güzelliğine benzer bir güzelliğe bağımlı güzellik derken yargımızda saf olmadığını ifade eder. Çünkü o sadece bir duygu doyum veya hazzın ifadesi olmayıp kendi içinde de kavramsal bir öge içerir der. Özgür güzellik ile bağımlı güzelliğe dair ayırım yaparken, estetik yargı nesnel bir amaçlılık ihtiva etseydi, bir şeyin iyi olduğunu öne süren yargı gibi bilişsel bir yargı olurdu. Nesnenin özgür değerlendirilmesinde amacın yarattı̆̆ duygu temel olduğunu ifade eden Kant, güzelden duyulan hazzın nesnenin ne olduğunun düşünüldüğü değil ama tasarımla birleşmiş salt estetik bir haz olacağını söylemektedir. Bağımlı güzellikte ise nesnenin amacına bakan ve nesnenin güzelliğinde nitelikten başka bir şey görmeyen, başka bir değerlendirme niteliğinde aynı nesne karşısında farklı hatta karşıt bir yargı ortaya koyabilecektir. Güzellikten alınan haz ikincisinde içsel bir amaca ve kavrama dayanacağından entelektüel bir haz olacaktır (Cevizci, 2010: 756).

Farklı coğrafya ve kültür içinde doğmuş, büyümüş bireyler, güzele ve beğeniye dair aynı nitelikleri baz alırken, bazen de sahip oldukları kültürün, yansıması olarak farklılık göstermektedirler. Ancak burada yine estetik beğeni ve güzele dair niteliklerin belirlenmesinde, yine bireyin kendi beğeni ve yargısına dair sahip olduğu estetik bilinç rol oynayacaktır.

Böylece yüksek beğeni sahibi insan kendini keşfetmesinde, hem entelektüel bilgiyi zorunlu olarak elde ederken, bir yandan da daha özgür bir yaşamı hak edecektir.

Estetik deneyim, kavramsız fakat zorunlu bir haz ve hoşnutluk olarak, güzellik ise bu zorunlu haz ve doyumun nesnesi olarak tanımlanmaktadır Özgür ve saf bir estetik yargı ve deneyime özgü zorunluluk, tüm teorik ve pratik zorunluluk ve gereklilikten farklı bir içerikle karşımıza çıkmaktadır. Estetik yargı ve güzellik bağlamında, olumsal ve keyfi bir bireysellik ve tikellik değil, evrensel ve bağlayıcı bir zorunluluktan söz edilebilmektedir. Bu kavramsal bir zorunluluk olmaktan çok, algılayan 
öznenin transendental formuyla, estetik nesnenin, yani güzel nesnenin kendine özgü içsel formunun çakışmasına dayanan estetik bir zorunluluktur (Orman, t.y.: 152). Kant'a göre bir şey güzeldir söylemi, onu teorik ve pratik bağlamda temellendirmektir. Oysa bundan daha çok, diğer öznelerin algılama yetisine dayalı estetik yargısı geçerliliği düşünülebilir. Bu nesnel ve teorik bir zorunluluğa değil, estetik açıdan öznel bir zorunluluğa işaret etmektedir. Buradaki öznellik bireysel ve olumsal değil, türe özgü transendental bir öznelliktir.

Sanattan alınan haz insanda uyandırdığı mutluluk ve arınmayla gerçekliğin baskısından uzaklaşıp onu mutsuz eden bütün olumsuzluktan kurtulmanın sağladığı bir rahatlık ve dinginliktir. Aristoteles'inde ifade ettiği gibi bir ölü hayvan imgesinin bize verdiği zevkin ancak, sanatçının üstün becerisiyle ve ürettiği eserin gerçekdışı özellikte olması, bunun da mutsuz ve huzursuz olan izleyiciyi bir şey yapma zorunluluğundan kurtarmasıyla açıklanabileceği ileri sürülür (Lenoir, 2003: 47). Burada eserin ayrıntılardan uzaklaşıp, eserdeki nesnenin özünü koruması, sanat alımlayıcısının ise her şeyi bir yana bırakıp sadece eserden aldığı hazza yönelmesi düşünülebilir.

Bir sanat yapıtının benzersiz niteliğinin hem deneyimden, hem doğadan bağımsız bir kaygı tasavvur edilmiş bir idede aranmaması gerektiğini söylemek mümkündür. Sanatta, bireyin yaşanmışlıkları ve deneyimleri imgelemsel süreçte ortak noktada yer almaz. Eser, yaşanmış deneyim, sanatsal seçimler ve kullanılan malzemenin kendine özgü kuralları arasındaki etkileşim süreci aracılığıla bu etkinliğin somutlaştırılma ve entelektüel algılamaya sunulma şeklidir. Eserde gerçekleştirilecek kendi içinde kusursuz bir idea düşüncesi modern estetiğin gündeminde de yer bulmuştur (Eco, 2017: 199) Gelişen teknoloji çağında entelektüel algılama bireye yeni düşünce, yeni duygular, yeni hazlar alacağı yaşamlar sunmaktadır. Bu gelişme sanat alımlayıcısını da etkisi altına almaktadır. Entelektüel bir yaşam içinde kendini tanımlamak isteyen insan, yeni haz ve beğenilere göre kendini yeniden tanımlamış ve kendi olmanın zevkini keşfetmiş ve deneyimleriyle bunu ifade etmeyi öğrenmiştir.

Entelektüel yaşam; sanat, kültür, inanç, ahlak, siyaset ve bir çok alanda insanın, dünyaya bakışını, onu yorumlayışını ve anlamsal mahiyette sorgulamasını etkin kılmıştır. Yeni yaşam koşulları, gelişen teknoloji buna bağlı olarak, insanın antikçağdan bu tarafa bir çok felsefecinin öğretisinde de yer alan hedonizm anlayışının yansıması sanat ve sanat eserinde de farklılık göstermiştir. Antik çağdan bu tarafa sanatsal bir ifadenin sonucu olarak karşımıza çıkan sanat eseri, insan zihninin ve ruhunun sahip olduğu zenginliği estetik bir beğeni ile ortaya koymayı amaçlamaktadır. 15. yüzyıldan sonra insan evreni sorgularken, sanat eserini ve güzeli algılayan olarak, deneyimlerinin, bilgisinin ve güzelin, duyumlarına hitap etmesine bağlı olduğunun farkına varmıştır.

Eserler karşısında entelektüel yaşam ve algı, sanat eserleri karşısındaki tepkimizin oluşmasında estetik zevkin ve inceliğin rolünü açıkça ortaya koymaktadır. Sanattan alınacak haz sahip olunan estetik beğeni ve estetik yargı ile niteliğini ve niceliğini ortaya koyarken, eser karşısında estetik tavır öznenin entelektüel birikimiyle ve alacağı haz ile var olduğunu kanıtlamaktadır.

Entelektüel olmak ise bir yerde insan düşüncesini ve insanlar arası iletişimi kıskacı altına alan klişeleri ve indirgeyici kategorileri kırmak olarak tanımlanabilmektedir. Entelektüel, mümkün olduğunca geniş bir halk kesimine seslenir, bu kesim onun yetiştiği ortamın, sahip olduğu dilin ve milliyetin sağladığı, çoğunlukla da başkalarının gerçekliğini görmesini engelleyen birer perde işlevi gören, tabuların ötesine geçebilmektir (Edward, 2015: 13). Bu bağlamda edinilen bilgiler alımlayıcının entelektüel birikimi sayesinde sanatın özünü ve yapısını nasıl yorumlayacağına dair bilgi vermektedir. $\mathrm{Bu}$ yorumlar ise sanat tüketicisinin ölçütünü belirleyecek olan önemli bir ayrıntı olacaktır.

Sanat tüketicisinin beğenisini, sanat eleştiricisinin, sanatçının yaratımlarında bulunduğu eleştiri ve salt estetik mücadelenin sonucu belirleyecektir. Sanat eserinin yaratıcısına kendi yaratımının ne denli etkili olduğu ve eserin uyandırdığı eğilim ile kendi amacı arasında ne denli uyumu olduğu üstüne bir eleştiride bulunacaktır. Dolayısıyla sanat eleştirmeni sanatçının yaratıcı etkinliğinden 
etkilenerek temsilcisi olduğu toplum kesiminin entelektüel durumu ve estetik beğenisiyle eser arasında en yüksekliğinden bir uyum sağlamaya çalışacaktır.

Sanat 'tüketimi' ile sanatsal üretim arasında ilişkinin düzenleyicisi olup, toplumun sanat yaşamındaki 'tersine bağlantı' mekanizması olarak işlev görecektir. Sanat yapıtının eleştirel bir çözümü ve değerlendirmesiyle, sanat yapıtının sanatsal kültür içindeki somut yaşamı 'tamamlanır', daha doğrusu tarihsel yaşam döngüsü tamamlanmış olmaktadır (Lenoir, 2003: 578).

Entelektüeli tutkulu bir toplum anlayışına ve düşüncelerini, son derece etkileyici bir biçimde ifade etme yeteneğine sahip, bağımsızlı̆̆ına çılgınca düșkün birey olarak tanımlayan Amerikalı sosyolog C. Wright Mills'e entelektüelin önünde çok önemli bir görev var olduğunu söylemektedir. Mills bunu şöyle ifade eder.

"Bağımsız sanatçı ve entelektüel sahiden yaşayan şeylerin basmakalıplaştırılmasına ve sonuç olarak cansızlaştırılmasına karşı direnebilecek ve mücadele edebilecek donanıma sahip, sayıları gittikçe azalan birkaç kişiden biridir. Artık gerçekten yeni düşünceler geliştirmek için modem iletişim araçlarının yani, modern temsil sistemlerinin bizi gömdükleri klişe görüş ve düşünce batağının maskesini indirme, sürekli olarak bunların etkisini kırma kapasitesi gerekir. Bu kitle sanatı ve kitle düşüncesi dünyaları giderek daha fazla siyasetin taleplerine maruz kalmaktadır. Entelektüeller zamanlarına ait insanlardır" (Edward, 2015: 36). Arnold'ın deyimiyle, "insanın aklına estiği gibi davranmasını engellediğini göstermek için entelektüellere ihtiyaç duyulmaktadır" (Edward, 2015: 43).

Modern çağın sanatçısı olmak, modernizmin yarattığı entelektüel insanı anlamak ile anlam bulacaktır. Sanatçının modern hayatla sistem arasında kalan bireyin tüketici olarak sanatçının eserini yaratma boyutunda önemli bir yeri olacaktır. Sanatçı eseri yaratırken kendinde var olan tinsel ve estetik bilgisi onun bu süreçte entelektüel bir haz almasını sağlayacaktır. Sanat eserinin sahip olduğu estetik ögeler, sanatsal değeri ile ilgiliyken onu yaratan sanatçının entelektüel boyutu, etkileyen diğer bir unsur olarak karşımıza çıkmaktadır.

Sanatçı, İçinde yaşadığı çă̆ın insani değerlerini ortaya koyması ve gerektiğinde bu değerlerin sorgulanmas1, onun entelektüel duruşunu ortaya koymaktadır (Serdaroğlu, 2015: 85-101). Eserin içerdiği muhteva, sanatçının yaşamındaki tercihleri ve evren ile bir tür hesaplaşması olarak karşımıza çıkmaktadır.

"Sanatçının entelektüel niteliğini belirleyen eserin içine neyi aldığıdır. Bir sanat eseri öncelikle sanatsal nitelikleri değerlendirilir. Bunun yanında, insanın içinde yaşadığı durumla ve çağ ile de ilişki içinde olması onun değerini artırmaktadır. "... Sanatçının kendi insan imgesini kendi çağının gerçekleri içine yerleştirmesi, kendi insanını veya insanlarını çağının sorunlarından seçtiği ilişkiler içine sokmasıdır" (Kuçuradi, 2010: 13).

İçinde yaşadığı sosyal çevre bireyin kişisel gelişiminde önemli bir rol oynamaktadır. Yaşam sanatçının oluşturduğu deneyimlerin bir yansımasıdır. Sahip olduğu deneyimler ve yaratıcı bilinci aynı zamanda onun entelektüel tarafının ortaya çıkmasına olanak sağlayacaktır.

"Değerlendirmek, değerlendirilenin kendi alanı içinde özel durumunu görmek ve göstermektir. $\mathrm{Bu}$ bakımdan değerlendirme, her şeyden önce bir bilgi sorunudur; değerlendirilen şey bakımından bir bilgi problemidir; doğru veya yanlış değerlendirmeler yapılabilir. Doğru değerlendirmeler objelerinin değerinin bilgisini sağlayan değerlendirmelerdir" (Kuçuradi, 1971: 26).

Yaşadığı çağın entelektüeli olmak belki de insanı bir sonraki dönemin gerçekliğinde onu geride bırakacaktır. Her bilgi kendi dönemi içinde belirleyici olmaktadır. Bireyin içinde yaşadığı sosyal çevre, aldığı eğitim onun kültür seviyesini belirlemede rol oynayacaktır.

Toplumun yaşam biçimi; inancı, gelenek ve görenekleri bireyin aldığı eğitim, yaşadığı sosyal çevrenin kültürünü, şekillendiren unsurlardır. Kültür’ün işlevi; “... çeşitli açılardan çizilebilen bir insan 
grubunun yaşayışını ve bu yaşayışın görünümlerini (...) belirleyerek; o grupta uzun ya da göreli olarak kısa bir süre geçerli olan (egemen olan) insanı görme tarzını ve değerlilik anlayışını algılayabilmesine yardımcı olmaktadır..." (Kuçuradi, 2009: 57-58). Dolayısıyla, Peter Dollot'unda ifade ettiği gibi

"Eğitim, öğretimle kültür arasında bir evredir. Kültürde ise insan tarafindan kendisi ve diğerleri; kendisi ve kültürün nesneleri arasında kurulan bir denge ilişkisine atıf vardır”. Jean Paul Sartre'ın ise, “...kültürlü insan, dünyadaki durumunu anlamasına yarayan bilgiyi ve yolları edinmiş olan insandır, entelektüel, sanat ve sanatçı arasında bir bağ kurulabilir" demektedir. Andrei Tarkovski'in ifade ettiği ise; "sanatı bir üst-dil olarak tanımlar ve köklü bir iletişim işlevi olduğunu, insanın ruhuna seslendiğini, onun manevi yapısını şekillendirdiğini dile getirir" (Aktaran: Serdaroğlu,2015: 85-101) demektedir.

Sanatın en önemli özelliği bireyde estetik tavrı ve beğeniyi oluşturmasıdır. Sanat izleyicisinin yaşama kattığı sanata dair değerler onun hayatını da güzel eser tadında geçmesini olanaklı kılacaktır. Bir yerde, "Eserde anlatılan his ne olursa olsun, sanat tüketicisinin yaşantısı her şeyden önce estetik bir yaşantıdır, yani sanat eserindeki güzelliğin tadılmasıdır” (Moran, 2012: 96). Susan Sontag “... bir sanat yapıtının içeriği olmaması, dünyanın hiç içeriği olmamasından farklı bir anlama gelmez" (Aktaran: Serdaroğlu, 2015:85-101) demektedir. Sanatta insana özgü derin bir kavrayış gücü, hayatı ve varlığı değerlendirme ve yorumlama özelliği vardır. Sanat eseri, kendine has estetik ve biçimsel özellikleriyle insanları büyük oranda etkileme gücüne sahiptir. Bunun nedeni olarak, sanat eserinin, söylenenleri doğrudan değil, dolaylı yoldan söylemesi gösterilebilmektedir. Sontag "Sanat yoluyla edindiğimiz bilgi bir şeyin kendisinin 'bilgisinden çok, bir şeyi bilme biçiminin ya da biçeminin yaşantısıdır' der. Yani sanatçı, dile getirmek istediği içeriği, o içeriğe uygun bir biçim içinde var etmektedir. "Sanatçının yaptığı şey, durumları belli sınırlar içinde göstermek; sayısız olaylar, ya da olabilecek olaylar arasından en önemlilerini çekip çıkararak, onlara yeni boyutlar kazandırarak değerlerini belirtmek; başka insanların da onların anlamlarını görebilmesini sağlamaktır" (Kuçuradi, 1999: 9).Sanatçı içinde barındırdığı duyguları bir şekilde ifade etme ihtiyacı duymaktadır. Bu ihtiyaç onu yaratma eylemi içine dâhil ederken, bu süreç içinde alacağı hazda mutlu olmasına neden olacaktır. Eserde var olan nitelikler, sanatçının sahip olduğu entelektüel deneyim ile kişiliğinin bir yansıması olacaktır. Bu bağlamda eserin güzelliğinin ölçütü sanatçının kişiliği ve entelektüel deneyimi ile doğru orantılı olacaktır. "İyi sanatçı bizlerin insan yaşamındaki zorunluluğun yerini görmemize, katlanılması gereken şeyleri, yapıcı ve bozucu şeyleri görmemize ve korkunç ve absürd de içinde olmak üzere gerçek dünyayı... Gözlemleyebilmek için düş gücümüzü arttırmamıza yardımcı olmaktadır" (Murdoch, 1992: 47).

Sanatçının, yaşanan olayları kanıksamadan, olaylara belirli bir mesafeden bakabilmesi büyük önem arz etmektedir. Sanatçıdan bunu bir bilim adamı, sosyolog, siyasetçi ya da eğitici edasıla yapması beklenemez. Sanatçı her şeyden önce, bunu sanatın diliyle ortaya koyması gerekmektedir. Aksi takdirde, ortaya koyduğu, sanat eseri olmaktan çıkacaktır. Sanatç1....özgürlüğe seslenerek, okuyucuyu, kendi özel yaşamını ... yüzleşmeye çağırır. Çağııırken ahlak dersi vermeye kalkmaz, ama tersine, ondan yaşamını tekilliğin ve evrenselliğin çelişen birliği olarak yeniden yaratabilecek estetik bir çaba bekler" (Sartre, 2014: 84). Sanatçının bu özelliği onu özgür kıldığı kadar, evrensel boyutta eserler yaratmaya zorunlu k1lacaktır.

Sanatın özgün anlatım dili ile birlikte bu sorumluluğu ve bilinci alan sanatçı sahip olduğu entelektüel tavır ile, insanları herhangi bir bireyden daha çok etkileyebilecektir. İnsanlık adına daha kalıcı izler bırakabilecektir. Eseri meydana getirirken sanatçı estetik deneyimin ve bilincin onu nasıl biçimlendirdiğini, derin ve düşünsel olarak nasıl etkilediğini, onlara yeni bakış açıları sağlamasına tanıklık etmektedir. "Sanat yapıtının başardığı, bizi yargılama ya da genelleme yapmaya götürmek değil, tekil bir şeyi görmemizi ya da kavramamızı sağlamaktır" (Sontag, 1998: 36). Sanatçının sanat eserini meydana getirirken, esere yansıttıkları bir yerde sanatçının dünya ile bir tür hesaplaşmasının sonucu olmaktadır. Sanatçının entelektüel niteliğini belirleyen, neyi eserin içine aldığıdır. Eserin 
evrensel nitelikleri taşıması, sanatçının entelektüel bilgisinin bir yansıması olacaktır. Sanatın, etkileyici özelliğini doğru kullanmak büyük önem taşımaktadır. Edman (1991:54) ifade ettiği gibi, sanat zevki ile sanat eserleri kültürel olarak İyi hayatın neye benzeyeceğini bize sezdiren habercileridir.

Bir sanat yapıtı veya bir düşünce sistemi, büyük bir bölümü yapıtın veya düşünce sisteminin ait olduğu, belirli bir düzeyde gerçekleşen karmaşık bir etki ağından doğmaktadır; bir sanatçının tinsel dünyası kendinden önceki sanatçıların tarz geleneklerinden etkilenir ve onlar tarafindan belirlenmektedir; bu tarzın etkisinde de, dünyayı yeniden anlamlandırmak farklı bir açıdan bakmayı öğrenmiş olmaktadır. Yaratacağı yapıt, içinde bulunduğu çağ ile belki çok zayıf bağlantılara sahip olacak, belki de resmin gelişiminin bir sonraki aşamasını ifade edebilecek veya çağdaşlarına yaşadıkları dönemin açık görünmeyen derin boyutlarını ifade edebilecektir (Eco, 2016: 60).

Genellikle sanat eseri tinden doğduğu için, onun kendi nedeni olarak öznel üretici bir etkinliğe gereksinimi vardır. Bu etkinliğin bir ürünü olarak sanat eseri, başkaları için, yani kamunun seyri ve duygusu için vardır. O, sanatçının hayal gücünü ifade etmektedir.

Sanat eserinin öznel iç bilince nasıl ait olduğunu, her ne kadar öznel iç bilincin ürünü olarak sanat eseri henüz edimsellik içinde doğmamış, yalnızca yaratıcı öznellik, yani sanatçııın dehası ve yeteneği tarafından şekillendirilmiş olsa da (Hegel, 2015: 279). Düş gücünün (Phantasie) en belirgin sanatsal yetenek olduğu söylenmektedir. Yine de bu durumda, düş gücünün tamamen edilgin hayal gücüyle (Einbildungskraft) karıştırılmamasına özen gösterilmesi gerekmektedir. Düş gücü yaratıcıdır. Sanatçı, insanı ilgilendiren şeyi belleğine nakşeder ve derin bir tin de, bilincine farklı konular yerleştirecektir. Düş gücü, içsel ve dişsal gerçekliğin bu salt özümsenmesinde durup kalmayacaktır. Çünkü ideal sanat eserinin asıl sağladığı şey yalnızca içsel tinin, dışsal biçimlerin gerçekliği içerisindeki görünüşü değildir; bunun tersine dışsal görünüşe ulaşması gereken, edimsel dünyanın mutlak hakikati ve akılsallığg olacaktır.

Sanatçının bilincinde var olan ve onu harekete geçiren, sadece seçmiş olduğu özgül konunun akılsallığı olmamaktadır, bunun tersine, sanatçının, bu konunun özselliğini ve hakikatini bütün alanı ve bütün derinliği içerisinde düşünüp taşınması gerekmektedir. Zira düşünüm olmadan, insan, kendi içinde var olanı zihnine getiremeyecektir. Bu nedenle her büyük sanat eserinde derin biçimde kurgulanıp tasarlanmış, düşünülüp taşınılmış olduğunu fark edilebilmektedir. Sanatçı, kendisinde yaşayan var olan şey, zihninde şeklini benimsemiş olduğu biçimler ve görünüşler içerisinde, betimlemek zorunda olmasıdır, çünkü sanatçı, bu biçim ve görünüşleri kendi amacına tabi kılabilmesi onu, kendi adına, özünde hakiki olan şeyi benimsemesine ve bunu eksiksiz biçimde ifade edilmesine olanak sağlayacaktır (Hegel, 2015: 281).

Eğer bir sanatçının yaratımı, yeti ve ustalıkla koşullanmışsa, o zaman sanat algısı da, oradaki sanat alımlayıcı bireyden, ortak yaratım veya sonradan yaratım olarak, kendi yansımasını bulmuş ustalık ve yeti biçimlerini isteyecektir. Bunlardan birincisi, sanat algısında, tıpkı ustalık gibi, sanat eseriyle doğrudan ilişkiden ve onun incelenişinden gelen yatkınlık biçiminde karşımıza çıkmaktadır. İkincisi ise, algılayan kişide belirli bir eğilim olması biçiminde, yani bir sanat tarzı dili içinde kendisine iletilmiş olan bir sanatsal bildirimi o kişinin özümleyebilmesi yeteneğinde görülmektedir. Kagan'nın (2008:340) aktardığı gibi; Stanislavski'nin, yalnız istidatlı oyuncular değil ama aynı zamanda, istidatlı izleyiciler de olduğunu söylemesi boşuna değildir. Aslında, müzikten, resimden, danstan, şiirden keyif almak ve bu etkinlikleri sevme daha çocukluktan başlamaktadır ve tıpkı sanatsal bir çalışma yapmak için olduğu kadar sanata dair yapılmış şeyleri algılamak için de daha doğuştan bir eğilimin kendisini belli etmesi gerekmektedir. Algıyla dair bu yetiye beğeni denilmektedir.

Sanat algisı sorununa estetik kuramında çok önceden değinilmiştir. Aristotelesin "katharsis" öğretisi (sanatı algılama sürecinde insan ruhunun "arınması" öğretisi), bu sorunu çözmek için girişilmiş ilk çaba olarak görülmektedir. Estetikçilerin öğretileri içinde ta baştan beri yer almakla 
birlikte, bu soru her zaman için estetikçilerin ilgisini çekmeye devam etmiştir. Nedenine gelince, sanat algısı sorununun, bilimsel araştırmada çok zorlu ve karmaşık bir yerinin olmasındandır. Bir kere sanat algısı, bilincimizin ve bilinçaltımızın derinlerinde dolaşan ve sağlam bir nesnel çözümleme yapmaya çalışmaktadır. Aslında dış görünüş biçimi göstermeyen ve herhangi bir temel oluşturmayan bir iç psikolojik süreçtir. Diğer bir sorun ise, her bireyde kendine göre yol alan, bundan dolayı da her kişide çeşitli etkenlere göre değişen, bütünlükle kişisel, derininden, bireysel bir süreçtir (Kagan, 2008: 340).

Güzel şeyin olduğu gibi görülmesi gerekir ve sanat ürünü belirli bir görme tarzı düşünülerek meydana getirilmektedir. Potansiyel bir izleyicinin öznel görsel deneyimini öngörmektedir. Estetik olarak seyredilen ve güzelliğin oluşturucu ögesi olarak zevk alınan işlevinin öznel yönüne özel bir önem verilmektedir. Güzelde nesnel bir nitelik vardır, ama bu niteliğin göstergesi bizim bakışımızla verdiğimiz onaydır. Doğası gereği kendiliğinden hoşa giden ve bakan kişiye haz veren şeye, güzel şey denilmektedir. Görülür güzelliği de bilmek istenirse, dışsal görme duyusuna ihtiyaç duyulur ve güvenilir. İçsel görüşümüzün veya bakışımızın onayladığı ve haz aldığı güzellik veya zariflik, Guillaumea göre; bir nesnenin, sevgi içeren bir haz duygusu, güzelliği bilmek ve ona öykünme yaratabilmek için, bireye belirli nitelikleri göstermesi yeterli gelmektedir (Eco, 2017: 137-141).

İyi bir sanatçı olmanın, iyi bir alıcı olmanın, elbette bir başlangıç noktası vardır. Yaş söz konusu edildiğinde, bitiş noktası yoktur. Bitişi olmadığına göre de insan üretmek istediği an, gereksinim duyduğu yaşta sanatçı olabilmektedir. Eser almaya kalkıştığı an alıcı olabilmektedir. Yeter ki sosyo-kültürel ortam ona bu olanağı sağlanabilsin, gerek sanatçı gerekse eser, hem sosyo-kültürel ortamın bir ürünüdür hem de sanatın varlık nedenlerindendir. Bunlardan herhangi biri olmazsa sanat da olmaz. Ama bu ilgi özne de sonuç olarak sosyo-kültürel boyutun bir ögesi olarak işlev üstlenmektedir. Bir sanat eserinin doğru değerlendirilebilmesi için onun var edildiği zamana ve yere bakmak, bu zamanın ve yerin koşullarını bilmek adeta önkoşuldur. İşte değerlendirmede veya eleştiride bu önkoşulu gerçekleştirebilmek demek sosyo-kültürel boyutun bilincinde olmak ve bu boyutun hakkını vermek demektir (Erinç, 2013: 16).

Freud'a göre sanatçı öne çıkardığı ortaya attığı içeriğinin yansıttığı (projection) sanat yapıtı ile bilinçaltındaki yükten kurtulmuş olur bu ağırlığı dışarı atarak oluşturduğu sanat yapıtı sanatçının bilinç altından bir gölgesi durumundadır. Freud'un buzdağının suyun altındaki kısmına benzettiği bilinçaltı insanı sanatçı bilim adamı din büyük filozof yaptığı gibi hastada yapabilmektedir sanat yapıtı konusunu ve yapısını öncelikle sanatçının bilinçaltından aldığı için onun derinliklerdeki dünyasına yansıtmaktadır (Bozkurt, 2000:179). Bu nedenle insan ile dahi arasında da çok ince bir ayrım var olmaktadır. Sanat eserlerinde değişmeyen bir unsur vardır. Bu sanat eserinin kendisidir; bir de değişen unsur vardır ki oda sanat eserine yöneltilen yorumdur. Eser aynı olmasına karşın alımlayıcının entelektüel kavrayışına göre tanımlanacaktır. Eserin yorumlanması ve algılanması karşısındaki sanat izleyicisine göre anlam bulacaktır. Sanata, felsefeye ve esere dair entelektüel birikime, estetik bilince sahip olmayan bireye göre eserden alınan haz farklılık gösterecektir. Sanatçının eseri yaratırken ki aldığı hazzın eserde vuku bulması, onunla aynı düzlemde ki sanat alımlayıcısıyla ilgili olacaktır.

Sanatçının durduğu yere göre, nesneler ve insan figürleri doğrudan resim düzlemindeki yerlerini almaktadırlar. Bir ortaçağ resminde insanların ve nesnelerin göre boyutları, geometrik bir kurala göre değil anlatılmak istenen gerekçeye göre aktarılmaktadır. Klasik Çin manzara resimlerinde insan figürleri geometri düşünüldüğünden değil, doğal çevre insanı cüceleştirdiği için kimi zaman çok küçüktür. Sanatçı perspektifi düzenli uyguladığında yerleştirmeye özgü kimi diğer ayrıcalıklar geçersiz kalmaktadır. Böylece, Bizans ikonalarından İzlenimci manzara resimlerine kadar hiçbir temsili sistem kendinden önce gelenlerden mutlaka daha ileridir denilmemektedir. Her sanatçı kendisinin ve kültür koyduğu sınırlar dâhilinde çalışmaktadır (Murray, 2009: 32).

Sanatçı kendi eserini, sanatın ya da doğanın kendisine sunduğu birçok modelden esinlenerek ortaya koyduğu veya düzelttiği bu beğeninin üzerine kendisine doyum sağlayan biçimi bulmaktadır. 
Ortaya çıkan eser işte bu yüzden, bir bakıma, esinlenme ya da tinsel yetilerinin özgürlüğünden ortaya çıkmamaktadır. Eser, söz konusu yetilerin işleyişindeki özgürlükten uzaklaşmadan, düşünceyle uyumlu kılmak için, hatta acı veren bir yetkinleşmenin ürünü olarak ortaya çıkmaktadır (Lenoir, 2003:135). Estetik duygu uyandıran nesneler kişiden kişiye farklılık göstermektedir. Tolstoy'a göre sanat, özünde sanatçı denen kişinin, belirli göstergeler aracılığıyla, yaşamış olduğu duyguları bilinçli olarak başkalarına aktarmasıdır. Başkaları da bu duygulardan etkilenerek, bunlardan entelektüel bir haz alarak duyumsayacaktır.

Sanatçının, insanların duygusal ve tinsel sağlı̆g konusunda ahlaki bir sorumluluğu gündeme gelmektedir. Platon'da, bilindiği üzere, estetik ölçüt, ahlaki ölçütlere bağlı olmaktaydı. Tolstoy'a göre insanları olumsuz yönde etkileyen eserler gerçek sanat eseri değildir; kötü sanat ürünleridir veya sanat olmayandır. Bu yaklaşım, sanat eserlerinin içeriği ve ifade gücünü yoğunlaştırmaktadır. Biçim, duyguların doğru biçimde aktarılması için önemlidir. Sanatsal yaratım, zanaatlarda olduğu gibi maddesel bir gereksinimden çıkışını almamaktadır; algılanmış, bulanık, belirsiz duygulara netlik, açıklık kazandırmaktadır. Yaratma sürecindeki rahatsızlık, şüphe ve stres sonunda doyuma ve hazza ulaşmaktadır. Önceden algılanmamış, fark edilmemiş olanın açığa çıkarılmasıdır. Yaratım bu açığa çıkarılanın izleyene, okura, alıcıya iletilmesiyle, onlarda da benzer duyguları uyandırmasıyla tamamlanmaktadır (Büyükdüvenci, 2006: 47-50). Sanat eseri, izleyicinin okurun kısaca sanat alıcısının hissedebilmesi ve algılayabilmesi için duygu yoğunluğu ile başkalarınca görülmeyeni ve anlaşılamayanı fark edilmesini sağlayandır ya da sanatçının duygu yoğunluğunu ve ulaştığı hazzı yaşantılamak yaratılan eser, karşısındakilerin aldığı haz ve zevk olacaktır.

Sanatçının dünya görüşü, estetik kanıları, sanatın özü ve belirlenişi ve kendi anlayışı, belirli bir toplumsal çevre içinde oluşur ve onunla belirlenmektedir. Bu nedenle, sanatçının estetik bilinci içinde gerçeklesen sanatsal yöntem, bunu kavransın kavramasın, toplumsal tarihsel bir kategoridir. Dünya sanat tarihi bize şunu göstermiştir: sanatçının yaratıcı yönteminde barınan bireysel özellikler, sadece onun kendi özgül özelliğiyle değil, ama aynı sanatçının bilincinin belli toplumsal çıkar ve idealleri kendine almış oluşuyla da koşullanmış olarak ortaya çıkmaktadır. Dolayısıyla, sanatsal yöntem bir toplumun, bir sınıfın bir dönemin belirli özgül ideolojik-estetik gereksinimlerini yansıttığ1 için, son kertede, sadece bir sanatçının kendi kişisel özelliği olmamaktadır. Aynı zamanda, bütün sanat doğrultularının estetik temelini de oluşturmaktadır (Lenoir, 2003:604). Gerek sanatçının görevi gerekse sanat eserinin başarısı duyularımızı faaliyete sevk eden araçlar olmaktan çıkarıp açık ve seçik bir şekilde karşımızda duran şeyleri inşa eden araçlar haline getirilmesi ile ilgili olacaktır. Güzel sanatlarda duyuların durmasıyla tecrübe şiddet kazanmaktadır (Edman, 1991: 27).

Yaşam algısından farklı olarak, sanat algısında, bir başka bilgisel yönlendirme biçimi daha vardır. Eylem kişilerinin karakterlerinde ve canlandırılan sanatçının dile getirdiği düşüncelerin, sanatçının değere ilişkin bilgisi, sanatı algılamakta olduğu sırada insan açıkça biliyordur ki, karşısında yer alan olay bir yazar, bir ressam, bir tiyatro ya da sinema yönetmenince belli bir biçimde sahnelenmiş olup, kendisi bu sahnelemedeki anlamı, düşünsel olarak ne anlama geldiğini "bulup çözmek" zorunda kalmaktadır. Sanat algısı, bilinçli olsun olmasın, her zaman için sanat yapıtını yaşamın gerçekliği içine oturtmak durumundadır. Ama bu, ilkel anlamda, yani gelişmemiş bir beğeni sonucu, canlandırılan şeyle onun canlandırılışı arasında dıştan bir benzerlik var mı, yok mu diye bakma anlamında olmamaktadır. Derin anlamda, yani algılayan kişinin bir sanat eserinde insani varlığın gerçek sorunlarını arayışı anlamında olacaktır. Biçimci anlayışlarla bozulmamış, normal bir estetik bilinci, sanatta yaşamın imgesel bir modelini arar ve kendi bilinci üstüne buradan bilgi edinmektedir. Okuyucu ya da izleyici, sanatsal hayal gücünün, insan yaşamındaki ampirik verilerden bir sapma göstererek, masallarda, grotesk hikayelerde, ya da fantastik resimlerde, canlandırılan şeyin, aslında öyle olmadığını ve olamayacağını düşünerek hemen doyuma ve hazza ulaşmaktadır. İnsanlar için sanat, ancak onun yardımıyla, dünyada olup bitenleri görüp kavramamıza yardımcı olacak "bir tür dünyaya açılan bir pencere", sihirli bir küre (Kagan, 2008: 421) olacaktır. 
Oscar Wilde, nitelikli sanatın toplumun beğenisini etkilemesinin ve geliştirmesinin mümkün olabileceğinden söz etmektedir. Sanatçı, halkın beklentilerini karşılamak gibi bir kaygıdan uzak olmak zorundadır. Wilde, ayrıca halkta hem haz alma duyusu, hem de duyarlılık yarattığı için büyük bir tiyatro yapımcısını övmektedir. Demek oluyor ki Wilde göre sanat, bireysel kendini gerçekleştirme çabalarının ahlaki standartların ya da toplumsal önyargıların yol açtığı klişelere, kalıplara başvurmaksızın da paylaşılabileceği bir araç olarak nitelendirilmektedir (Wilde, 2014: 13). Bu anlamda, entelektüel bir tavır almak, bir entelektüel olmak anlamına gelmektedir. "Her türden sanatsal yaratı, gerçeklik üzerine, belli bir döneme yayılmış bir biçim eğiliminde saklı bir dizi ikna." (Eco, 1990: 14) gücüne sahip olacaktır.

Sanat toplumun sahip olduğu entelektüel yaşamın bir yansıması olarak karşımıza çıkmaktadır. Sanatçının, meydana getirdiği eserin nitelikli olması, toplumu da etkileyecek bir güç olarak karşımıza gelecektir. Eserden alınacak entelektüel haz, insanın kuracağı ilgi ve beğeni ile ortaya çıkacağı bilinmektedir. Sanatçının deneyimledikleri ve entelektüel birikimi ne kadar esere yansısa da karşısındaki sanat izleyicisinin algıladığı kadar olacaktır. Rûmî'nin dediği gibi 'Sen ne söylersen söyle, söylediğin, karşındakinin anladığı kadar olacaktır.'

Çağının teknolojisini ve entelektüel bilgisini yakalayan her toplum, sanata büyük bir ilgi göstermesi zorunlu bir gereklilik olarak önüne çıkmaktadır. Hızla gelişen dünyada her şey hızla tüketilmektedir. Sanat eserinin alımlayıcı tarafından kabul görmesi, onun sahip olacağı niteliklerin yanında haz ve mutluluk da vermesi gerekmektedir. Sanat tüketicinin alacağ 1 haz sanatçı ile kuracağ ilişiklik dışında, sahip olduğu entelektüel donanım ile doğru orantılı olacaktır.

Sanat eseri kendini ortaya koyan ve bunu sağlayan aklın gücünün bir yansımasıdır. Sanatçının ve sanat alımlayıcısının içinde bulunduğu entelektüel bilgi ve deneyim ise buna eşlik eden en önemli unsurdur. İnsan yaşam içinde var olabilmesi için gereken olanakları sağlayan ve onu hep bir üst seviyeye taşıyan aklı ve ona eşlik eden bilinci ile; düşünmeyi, yaratmayı, mutlu olmayı, haz almayı amaç edinmiştir. İnsanın düşünen bir varlık olması, onu hep yeni şeyler öğrenmeye ve yaratma olgusuna yönelmeyi zorunlu kılmıştır. İnsan algısının bilinmeyene yönelik merakı, aklın ve bilincin eşliğinde bilgiyle buluşmuştur. Entelektüel bilgiye sahip olmak, düşünce, yaratma, deneyim ve sanat algısının yeniden kurgulanmasına neden olmuştur. $\mathrm{Bu}$ kurgulanış, yaşamın içinde deneyimlediklerinden aldığı hazzı ve mutluluğu da farklı kılmıştır.

Sonuç olarak; sanatçının aşk ile var ettiği eseri ile kurduğu bağ ve oradan dışa yansıyanın izleyiciye ayna olması, belki de İnsana sunulan mucizelere tanık olma isteğinden kaynaklanmaktadır. Sanat eseri, kendi içinde gizlediği gücü karşısındaki insan aklının uzanabileceği en geniş alanlara kadar yayarak, insanlığın varoluş alanlarını genişletirken belki de kendi özünde yer alanı keşfetmesini sağlamaktır.

Hedonizm öğretisinin sonucu olan haz duygusu, insanın var oluşundan bu yana içinde barındırdığı en temel duyumlardan biri olmuştur. Haz yaşamsal gereksinimlerini karşılarken, insanı yeni şeyler keşfetmeye yönelten ve diğer canlılardan ayıran en önemli duygudur. Dinsel öğretilerin temelinde yer alan ve yasaklanan haz, diğer yaşamda ödül olarak önüne sunulmaktadır. Sanatın ve sanat eserin verdiği haz duygusu, insanı kendi içinde yer alan bilgi ve düşünceye doğru çekmekle kalmaz onu yetkinliğe ve sahip olduğu gücü hissetmesine neden olmaktadır.

"İnsanın sahip olduğu bilinç, kendi ile ötekiler arasında deneyimlediği özdeşik-ayrım ilişkileriyle kendini var kılmaktadır. Hazzın kaynağı bu bilinç hareketliliğinde gizlidir. Haz, benin kendisiyle buluşma, kendini onaylama, kendi varoluşuyla karşılaşma, kendine katılma halidir; haz, olmaktır, kendin olmak, kendini tanımak, bilmek, diğerleri arasında kendi olabilen bir etmen olmaktır. Bu yüzden aynı özellikler ve beğenilere sahip insanlar karşılaştıklarında durum, uyurken beynimizin, organlarımıza belli aralıklarla uyarımlar gönderip onların tepkileriyle kendi bütünlüğünü onaylaması da budur. Mitolojilerde de tanrilar kendilerini onaylayacak, kendine kendini anlatmaya yarayacak 
varlıklar yaratmaktadırlar. Varlığın neden var olduğuna verilen cevapları böyledir. 'Ayna olmak'! Aşk'da karşılıklı ayna olmaktır. Sanatsal yaratımlarımız da sanki tanrısal bir hazdır, çünkü yarattığımız eserler bize bizi anlatır, kendimizle yeniden tanıştırır" (Bilgiç, 2002; 30)

\section{KAYNAKÇA}

Bozkurt, Nejat (2000). Sanat ve Estetik Kuramları. Bursa: ASA Kitapevi.

Bilgiç, Meriç (2002). Erdem Kuramının bilinç felsefesinde temellendirilişi. Felsefelogos Dergisi 30 (19)

Bilgiç, Meriç (2002). Erdem Kuramının bilinç felsefesinde temellendirilişi. Felsefelogos Dergisi 30 (19)

Büyükdüvenci, Sabri (2006). Sanat ve Değer. Felsefe ve Sosyal Bilimler Dergisi, 2, 47-50

Dellaloğlu, Besim F. Sosyal Bilimler Felsefesi. Sosyoloji Lisans Programı. İstanbul Üniversitesi Açık ve Uzaktan Eğitim $\quad$ Fakültesi. https://www. academia.edu/13140568/Sosyal_Bilimler_Felsefesi_Sosyoloji

Eco, Umberto (2016). Açık Yapıt (Çev. Tolga Esmer). İstanbul: Can Sanat Yayınları.

Eco, Umberto (2017). Ortaçağ Estetiğinde Sanat ve Güzellik (Çev. Kemal Atakay). İstanbul: Can Sanat Yayınları

Edman, Irvin (1991). Sanat ve İnsan (Çev. Turhan Oğuzkan). İstanbul: Milli Eğitim Yayınları.

Erinç, M. Sttk1 (2016). Resmin Eleştirisi Üzerine. Ankara: Ütopya Yayınevi. Erinç, Sitk1 (2013). Sanatın Boyutları. Ankara: Ütopya Yayınları.

Hegel, Georg Wilhelm F (2012). Estetik Güzel Sanat Üzerine Dersler I. Çevirenler(Taylan Altuğ, Hakk1 Hünler). İstanbul: Payel Yayınevi.

Hegel, Georg Wilhelm F (2015). Estetik Güzel Sanat Üzerine Dersler II. Çevirenler. (Taylan Altuğ, Hakk1 Hünler). İstanbul: Payel Yayınevi.

Hutter, Michael-Throsby, David (2013). Paha Biçilemez Kültür, Ekonomi ve Sanatta Değer Kavramı (Çev. Ceren Yalçın). İstanbul: Sel Yayıncılık

Kagan, S Moissej (2008). Estetik ve Sanat Notları. (Çev. Aziz Çalışlar). İzmir: Karakalem Kitabevi

Kant, Immanuel (2016). Yargı Yetisinin Eleştirisi (Çev. Aziz Yardımlı). İstanbul: İdea Yayınevi.

Keeble, Brian (2016). Her İnsan Bir Sanatçıdır Geleneksel Sanat Felsefesi Okumaları (Çev. Tahir Uluç) İstanbul: İnsan Yayınları.

Kuçuradi, Ioanna (1971). İnsan ve Değerleri.İstanbul: Yankı Yayınları.

Kuçuradi, Ioann (1999). Sanata Felsefeyle Bakmak, Ankara: Ayraç Yayınevi.

Kuçuradi, Ioanna (2009). Uludağ Konuşmaları, Ankara: TFK.

Kuçuradi, Ioanna, (2010). Çağın Olayları Arasında, Ankara: TFK.

Lenoir, Beatrice (2003). Sanat Yapıtı. (Çev. Aykut Derman). İstanbul: YKY.

Murdoch Iris (1992). Ateș ve Güneş, (Çev. Serdar Rıfat Kırkoğlu) İstanbul: Ayrıntı Yayınları. http://www.scribd. com/doc/101034322/iris-mur doch-ateş-ve-guneş. Erişim Tarihi: 25.02.2017. Metis Yayınlar1. 
Murray, Chris (2009). 20 Yüzyıl Sanat Okuyanlar (Çev. Suğra Öncü). İstanbul: Sel Yayıncılık.

Orman, Enver (2014) Estetik. Auzef Ders Kitapları.İstanbul

Sartre, Jean Paul (2014). Aydınlar Üzerine, Aysel Bora (Çev.), İstanbul: Can Yayınları.

Serdaroğlu, Fatma (2015). Entelektüel Sanatçı İlişkisi ve Türkiye'de Entelektüelin Konumu. İletişim Kuram ve Araştırma Dergisi, say1 44, 85-101.

Shiner, Larry (2013). Sanatın İcadı (Çev. İsmail Türkmen). İstanbul: Ayrıntı Yayınları.

Sontag, Susan (1998). Sanatçı Örnek Bir Çilekeş, (Çev.Y. Salman ve M. Gürsoy Sökmen) İstanbul.

Tunal1, İsmail (2003). Marksist Estetik. İstanbul: Kaynak Yayınları.

Wilde, Oskar (2014). Sanatçı: Eleştirmen, Yalancı, Katil Estetik ve Etik Üzerine. Çevirenler: (Esin Soğancılar, Kaya Genç, Fatih Özgüven, Türker Armaner) İstanbul: İletişim Yayınları 